\title{
The Module of Power Point Optimization Training SDL Based to Improve the Teacher's Competence in Developing Learning Media
}

\section{Pilendia', S. Amalia}

${ }^{2}$ Physics Education, STKIP Muhammadiyah Sungai Penuh, Sungai Penuh e-mail: dwiptera@gmail.com ${ }^{1}$, shabrinaphyisics@gmail.com ${ }^{2}$

\begin{abstract}
This study aims to express the effectiveness of module development of power point optimizing training as a learning media. The module developed has several excellences such as the material presentation presented focusing on how to make a good learning media, started from the opening part, material, evaluation, references, completed with self assessment and presentation of Self Directed Learning $(S D L)$ based material which eases the teacher to study independently. The type of this research was R\&D with $4 D$ model. based on the observation result found that predominantly the teachers did not acquire power point yet. Based on the result of N-Gain test on pre-test and post-test score shows that the average score of $\mathrm{N}$-Gain is $>0,70$ (high category). The result of self assessment on each meeting shows that $75 \%$ teachers have achieved score 70 . Based on this data, it can be concluded that the module being developed is included into effective category in improving the teachers' competence especially in making technology based learning media.
\end{abstract}

Keywords: training module, PowerPoint

\section{Introduction}

Teachers are required to be ready competing in making the students learn started from analyzing, planning, developing, implementing, and assessing the learning based on ICT application. ICT in learning can be applied in the learning media. Learning media is the facility to visualize the learning process (Sulfemi, 2019; Rusby, 2017), in the form of device functioning to explain part or even a whole learning program which is difficult to be explained verbally (Hadibin et al., 2012). The usage of learning media in each learning process has become a demand or even a must to manifest the students' success in education, one of its main factors is the teachers' ability in using media in learning (Rozie, 2018; Alwi, 2017). ICT based learning media can ease students in understanding the learning material (Suprapti, 2016). The research results shows that the application of technology based learning media can improve the understanding and learning motivation of students especially in the field of science. In line with the technology development, various applications have been used as learning media such as prezi, lectora, and power point (Shanmugam \& Balakrishnan, 2017).

Power point is one of softwares which can be used as the learning media. Even though in the beginning it is designed for the usage of presentation in the company, but nowadays power point usage has entered the learning process. Beside that, Power Point is the application which can be accessed easily and available almost in all computers or PC (Personal Computer) (Kirova et al., 2016). Although nowadays there are many complex learning media developed based on adobe flash, lectora, prezzi, and so on, but the usage of Power Point is still frequently used by the teachers as the learning media (Berk, 2011). This is because Power Point can increase students' attention towards the learning (Nouri \& Shahid, 2005). By utilizing the menu obtained in Power Point enables to produce an attractive learning media. This is because the video, text, music, animation, and picture can be included into Power Point to support the learning material explanation. Some advantages of using power point are as follows: 1) the electronic format is extremely easy to be distributed to and used by students; 2 ) it can be combined with some media; 3 ) the file can

${ }^{*}$ Corresponding author.

Received 03 September 2019; Accepted 28 September 2020; Available online 01 December 2020 (C) 2020 JPI. All Rights Reserved 
be edited easily; 4) it is possible to be printed as Handout; 5) portable file (Jones, 2003).

The observation result at Integrated Islamic Elementary School (henceforth; SD IT)

Kerinci shows that there are still many teachers who do not implement technology based learning media yet such as the usage of Power Point. This can be seen from the table about the initial analysis result of teachers' knowledge on ICT based learning media especially Power Point which obtained from 24 SD IT teachers. Based on table 3, it can be seen that $87,50 \%$ teachers ever used printed learning media. This is in the contrary with the usage of non printed learning media (electronic) which is only $20,83 \%$. The low usage of electronic media is because of the teachers' less skill in using ICT. This also can be seen from the skill indicator using Power Point as the learning media which only reaches $25 \%$. In the usage of ICT based media especially Power Point, most of the teachers can only make the text, insert the picture, make animation, and diagram. The teachers still cannot make complex animation such as making the pulldown menu, running menu, making the score using action script, and hyperlink. Whereas by acquiring these things, the teachers can produce an interactive, dynamic, and attractive learning media.

The absence of training for the teachers at SD IT Kerinci Regency causes less knowledge of teachers on technology based learning media development. Therefore, it is necessary to conduct certain learning media development training to increase the teachers' professionalism competence. Training is one of ways for profession development (Supriyono, 2017). So that the training can run effectively, it requires teaching material which can support this process. One of teaching material which is commonly used in the training is module. Module is the teaching material which contains learning purposes which would be achieved, the materials, work sheets, and evaluation (Rasmawan, 2018).

Some community service journals show that the teachers' interest in Power Point based learning media training is extremely high. However, most of the training is conducted only using module. Mostly the training is conducted through demonstration (Permadina et al., 2017; Pinahayu \& Sriyono, 2019). Therefore, it needs certain practical and effective training module which can be used independently or structured in the training of Power Point based learning media.

Some materials frequently presented in the training of Power Point based learning media are very basich such as entering the text into the slide; adding new slide; selecting the slide design; moving the slide about to be edited; changing the view display; changing normal view to slide show; moving the slide order; copying the slide; deleting the slide; inserting the slide; entering the picture into the slide; entering the background into the slide; entering data, number, and footer into the slide; entering the table into the slide; entering graph into the slide; changing the graphic display; adding the graph title; formatting data series display; and entering animation in to the slide (Rusli et al., 2020). Other menu that were presented in the training module are such as making design of Power Point template and using the template design available, doing transition in each Power Point slide (Santoso, 2019). The training uses the training module which only consists of three chapters that discuss in general about presentation namely how to make and same the file, uploading the background, printing the slide, and linking the slide (Shedriko et al., 2018). The quiz material taught in the previous research could only give correct or incorrect response (Alimudin et al., 2019). In other words, the quiz cannot accumulate the students' score yet. One of this training module excellences is the presence of material of making evaluation for the students by using action script which can accumulate the students' total score, showing how many correct score, the incorrect score, and the score obtained, and the scoring system can be managed by the teacher in action script. For the animation material, it is also still extremely simple such as making animation to move the things using animation (Fahriannur \& Siswanto, 2016). In here it can be seen that the material given is not full and complete started from the learning opening (cover and main menu, core activity menu (learning material or sub material) and menu to close the learning (Evaluation or Quiz).

Based on problems that have been explained above and the presence of gap between reality and expectation, then it is necessary to make more specific and focus power point 
based learning media, thorough material presentation, and can facilitate the teacher in independent learning (self direct learning).

\section{Method}

This research was type of research and development of 4D model. 4D model consists of 4 stages namely define, design, develop, and disseminate (Thiagarajan, 1974). This research was started with define stage. Define stage was conducted in the stages such as preliminary-final analysis, users' analysis, assignment analysis, concept analysis, and instructional purpose analysis. Next, the design stage covers standard test arrangement, media selection, format selection, and initial design. Develop stage aims to produce a valid, practical, and effective media. Develop stage conducted validity test, practicality test, and effectiveness test on the media being developed. The last stage is disseminate, conducted to promote the development product so that it can be accepted by users either individually, in group, or system. This research dissemination was conducted at SD IT of Al Madina, Kerinci Regency.

The development flow using 4D model can be seen in Figure 1. In this article, the discussion will be focused on the result of develop and disseminate stages. In the stage of valid product development had been tested at SD IT of Nurul Qur'an to see the product effectiveness. Then disseminate stage was conducted to find out the product effectiveness with different schools. In the stage of product distribution was tested at SD IT of AI Madina. The effectiveness data obtained from the result of self assessment which had been filled in by the teachers in each end of the chapter in the module.

The self assessment used likert scale with assessment criteria as follows: 1) if the material mastery $0-25 \%$; 2) if the material mastery $26-50 \%$; 3) if the material mastery 51 $75 \% ; 4)$ if the material mastery $76-100 \%$.

The product usage is said effective if $75 \%$ of training participants can acquire the material or has achieved score 75 and produce a learning media based on the module instruction.

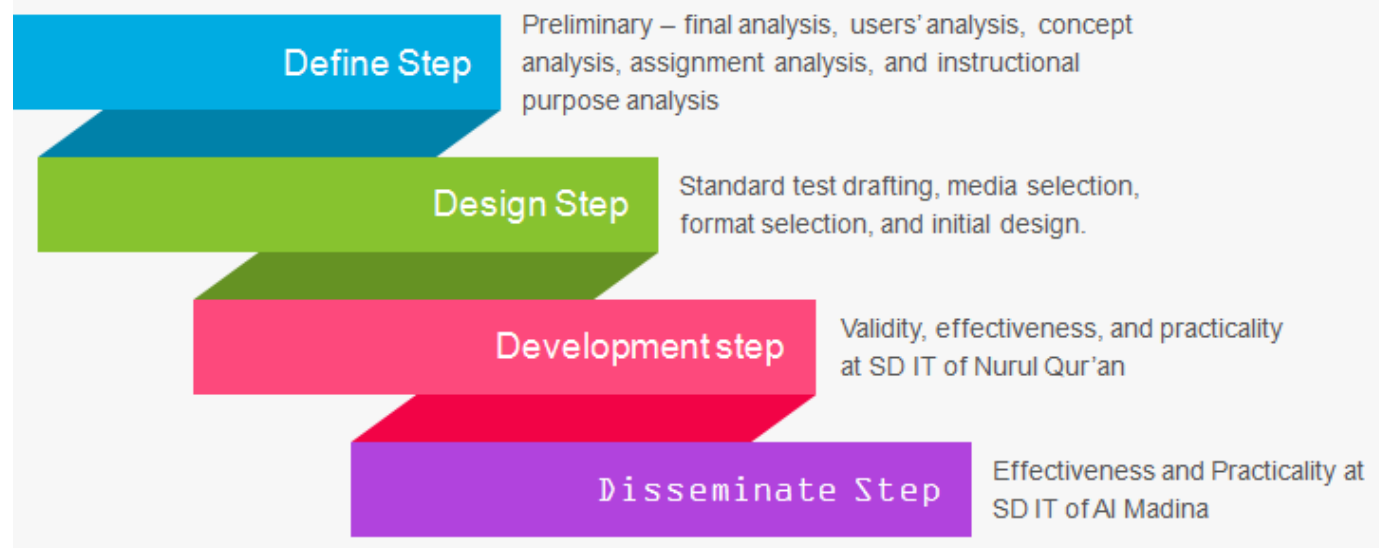

Figure 1. The Research Flow of 4D Model

\section{Result and Discussion The Result of Define Stage}

The result of define stage shows that an effective teaching material is necessary so that the training conducted can run effectively and efficiently such as the training module. So that the module being developed can become the effective solution for the teachers then assignment analysis and material or concept analysis were conducted. The assignment analysis produces some assignments which must be done by the teacher to achieve the indicator. In general the assignment that must be done by the students is making learning media with complete structure with dynamic and attractive display consisting of the users' instruction, main menu (introduction, material, evaluation, and references), sub menu (KI, 
$\mathrm{KD}$, and Indicator) and the compiler. Considering most of teachers are not familiar with the usage of power point then the material presented started from basic such as making the cover. While for the assignment, so that the training participant can work independently then the assignment given in the module in the form of self assessment. The result of instructional purpose analysis obtained a number of learning indicators which would be learned in each learning activity. The indicator would be explained under the title of each chapter in this module.

\section{The Result of Design Stage}

Design stage (design) produces the product in the form of training module in optimizng power point as the learning media. The module produced is different from the module existed previously. Based on some previous research, then it can be concluded that the excellence of the module being developed in this research is the intact learning media material presentation started from the cover design, menu presentation, material, and intact evaluation making this module can be used by anyone, not only among teachers, but also beneficial for prospective teacher students as the reference in learning media course. From the side of material delivery presented in simple language and step by step followed by picture tutorial, easing the teacher in understanding the material. The evaluation which is in accordance with the indicator and presented in the form of check-list table with likert scale easing the training participants to evaluate the training achievement and also easing the training instructor in evaluating which materials had been or had not been acquired by the participants.

In chapter I making the cover, this chapter does not only present how to make the cover of attractive learning media, but also the tips on who to choose the color and what components must be in the main first page. Next in chapter II and III presented as how to make menu from learning media, in which the participants are also introduced to how is the menu diplay form in pull down and running. Until then the learning menu produced is seen dynamic and attracts the students' interest. Some sub menus are required in the learning such as menu of KI, KD, Indicator, Material, and Evaluation. Next is chapter IV is presented on how to make attractive menu evaluation, either for multiple choices or essay. In here also seen that the excellence of this module is the presence of score making material by employing action script until it does not spend many slides. Beside that the presence of action script menu eases the teachers in managing the evaluation score later. This also eases the students in the achievement which then if there is no teacher, the students can find out their own score. This far most of evaluation presentation only by using correct/incorrect method until the students cannot know their score. Beside using action script scoring, also presented the material with correct/incorrect response for question example in material menu part made by the teacher. The tidy and intact material presentation are presented with self direct learning model, this self learning model eases the teacher in making certain learning media with complete and attractive components

In the previous research, the training participantas were not introduced to what components must be in making learning media. Most of the materials presented are about the basic of power point usage. Whereas the teacher must know more what components obtained in the learning media, and what kind of learning media would be made. In this module, there is discussion about the general description of learning media which must be made by the teacher and how to arrange the componnet of learning media systematically and seems interactive. Until the training participants have recognized the goal which would be achieved and what kind of media concept will be made.

\section{The Result of Develop Stage}

Develop is the development stage. The trial of valid product is conducted in this stage to find out its effectiveness. The product being tested consists of six chapters. However the product trial was conducted three times in face to face meeting only to overcome the obstacles faced by the teacher when learning independently. 


\section{The Result of Disseminate Stage}

Disseminate is the stage of module distribution. The module distribution is conducted to find out the module effectiveness on different subjects namely SD IT of Al Madina. Based on quantitative data, it can be seen that $75 \%$ of training participants have obtained the average score more than 70 . Until it can be concluded that the module usage has been included into effective category. Even though in each learning activity there was still score less than 80. In average the teacher obtains the lowest score in KB IV namely in material of making score on multiple choice questions. Some learning indicators at KB IV are; 1) showing developer menu; 2) making macro; 3) applying macro in start button; 4) applying macro in correct answer; 5) applying macro in wrong answer; 6) applying macro in the score button.

The interview result with some teachers show that most of the teachers experience difficulty in indicator 1 and 2 . This is because when appearing developer menu the teachers feel difficult to find developer menu in custom ribbon. While during making macro the teacher experienced difficulty when they must retype the macro codes and apply them on each symbol. The score more than 80 is in average obtained at KB I and IV namely in material of making the media cover and making the running menu. This is because the material presented is still basic and there is still change to have question and answer directly to the training instructor.

Based on the development result it can be seen that the training participants have been able to make technology based learning media especially Power Point. In Figure 2 (a) found out that the training participants can make pulldown menu in Power Point. By the existence of pulldown menu then the display of the learning media made will not show up if it is not clicked in the main menu. Until it saves the space usage in the screen. Figure 2 (b) shows that the training participants have made an answer response. When one picture is clicked, then each picture will show the correct or incorrect answer. Some participantes make creation on the appearing response with voice and some others with the writing. In figure 2 (c) can be seen that the training participants have been able to make action script in Power Point. Action script is useful for showing the score directly in Power Point. After the students filled in the multiple choice evaluation in Power Point. By the existence of this action script, it will save slide usage because the students' answer scores will be automatically saved when clicking the answer, and will appear when the students finished the evaluation. The total score will appear along with the answer number filled right or wrong by the students. The presence of pulldown menu, the running menu, making the score using auto script shows that there is knowledge improvement of the training participants which in the beginning could not make power point based interactive learning media.

The material which cannot be explained just through words can be explained through figure or video. For instance the event of iceberg eruption requires certain video so that the students can see the process of how an iceberg erupts without being exactly in that place. Another example is the process of eclipse occurance, the students cannot directly see it by using binoculars. However if there is power point based learning media which is completed with the video and animation of the eclipse process, certainly it will make the learning more fun and easier to be understood. Beside that multimedia has several advantages and make the learning more interactive (Dwyer, 1993). For example as made by one of training participants, the usage of multiple choice response in the form of voice and students can see the evaluation score directly will make the learning media being developed becomes more interactive.

Reviewed from the color combination, there are still training participants who do not know the principle of color selection yet. For instance the dark background color is filled with the dark color writing too. Until the writing cannot be seen clearly. Next from the side of the letter size, the letter size in the title and the content are not proportional yet. If used during the learning will make students sitting at the back difficult because the writing is less clear.

In the learning process, a teacher needs to design first the learning program, which means a teacher before teaching need to design the organization of clear learning material, design the class management, design the learning strategy, design the learning media and 
design the students' learning evaluation (Cut Fitriani, Murniati AR, 2017). Based on these findings, in the future it is expected to develop training module which in it also discussed about the principles of Power Point based learning media and how to use it in the class because the teacher is not only required to have the knowledge about the media only, but also must have the skill in selecting and using the media well (Rozie, 2018).

\section{The Result of N-Gain Test}

The increase of teacher's knowledge about the usage of ICT based learning media especially Power Point seen from the teachers' ability in the last meeting. The data were obtained and analyzed covering pretest and posttest data. Next the N-Gain of the training participants were counted. The description of pretest, posttest, and N-Gain can be seen in Table 1.

Table 1. The Analysis Result of Class Teacher Ability at SD IT

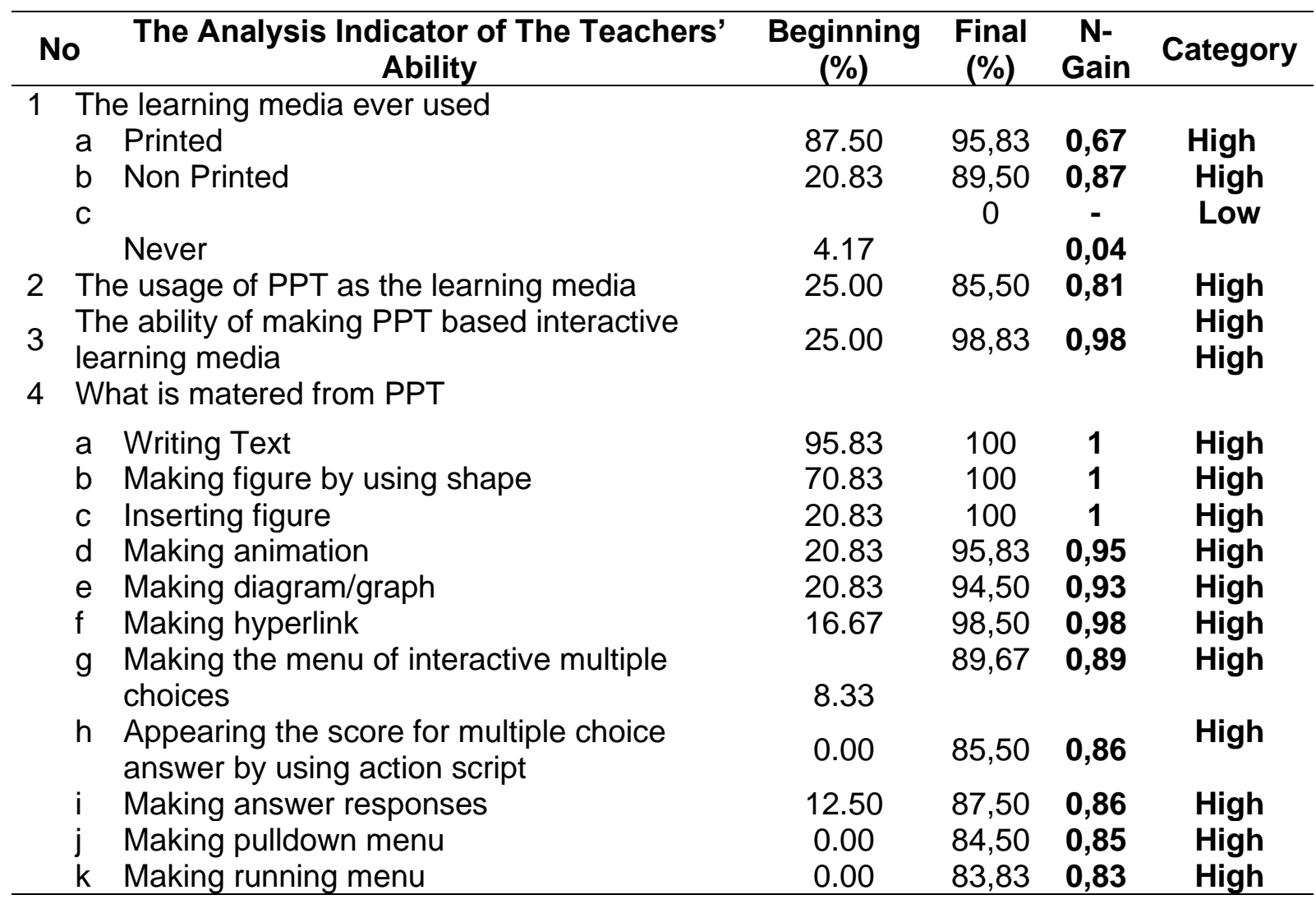

From the data in Table 1 seen that almost all scores experience increase and have high category. Only indicator of ever/not using learning media which the increase is in low category. It actually has positive value in which in the analysis of teacher's initial ability, there are $4,17 \%$ teachers who still never use learning media in the class. After a couple of weeks following the training of power point optimization as interactive learning media, the final analysis result of all teachers have used learning media in the class. It means in indicator of using learning media with point "never" becomes $0 \%$.

The indicator of using printed media and non printed media also experiences increase with $\mathrm{N}$-Gain value for each is 0,67 and 0,87 with high category. The next indicator is the usage of power point as learning media and the ability of making power point based interactive learning media, both indicators also experience increase with N-Gain respectively 0,81 and 0,98 which have high category.

Next fore the content mastery existed in power point, the one which experience the high increase with $\mathrm{N}$-Gain $=1$ is in text writing category, making the figure by using shape, 
and inserting figure. These three categories are actually included into the basic ability in power point, however when doing the initial analysis still found some teachers that do not acquire these, namely in the amount of $4,17 \%$ (writing text), $29,17 \%$ (making figure by using shape), and $79,17 \%$ (inserting figure). After following the training by using the module of power point optimization as interactive learning media, 100\% teachers have acquire those indicators.

In the content mastery in the power point, there are three indicators existed in the initial analysis result $100 \%$ teachers do not acquire them yet. These indicators are appearing the score of multiple choice menu using action script, making pulldown menu, making running menu. After following the training by using the mdoule, the teachers' ability in acquiring the three indicators increase with $\mathrm{N}$-Gain 0,86 (appearing the score of multiple choice menu using action script) in high category, 0,85 (making pulldown menu) in high category, and 0,83 (making running menu) also in high category.

Another indicator also experiences significant increase which beforehand only small parts of teachers who acquire them. These indicators with their increase ( $\mathrm{N}$-Gain) are making animation $(0,95)$, making diagram/graph $(0,93)$, making hyperlink $(0,98)$, making interactive multiple choice menu $(0,89)$, and making answer response $(0,86)$.

After conducting the analysis on all indicators, most of teachers have experience sufficiently significant increase. Some training participants have made creation of power point by following the stages obtained in the module such as in Figure 4 . This shows that the training module being developed is effective to increase the teachers' knowledge in making the learning media until at creation level (C6).

Some creation examples done by the training participants as in the learning media cover, the teacher can make the form or design different from the example obtained in the module. The training participants also do improvisation in making the running menu. In the module, there is only the example of making running menu from the right to the left. But in some training participants they make it from up to the bottom with different shape forms. Not onlythat, some training participants also do improvisation when making the answer response of multiple choices. In the module only presented the visual answer responses, but during the training so participants chose audio answer response after knowing the way how to insert the audio into power point. However some teachers still need guidance in making the media because of some factors. The supporting factors are namely 1) internal factor, such as the teachers' educational background, teaching experience, the material acquisition, the awareness to increase the ability, and others. The inhibition factos are such as the teachers' motivation in increaseing their quality (Yunus, 2016).

Overall the training participants have been capable of achieving the module demand namely making the learning media with compelete and interactive structure. Nevertheless, there are also several things need to be considered in designing the power point as the learning media such as considering the format and combination of various media for increasing the learning process (Pate \& Posey, 2016). The proportion of picture and audio in material presentation also must be balanced considering students' various modality. Most of the teachers choose figures. Whereas power point is not only effective for audio and visual students but also reading and kinesthetic (Ankad et al., 2015). Until it is very important to use multimedia in the power point media for elementary school students. This is because it can give direct experience (Diputra, 2016). By using multimedia in power point will enable the implementation of meaningful learning (Shah \& Khan, 2015).

Based on data analysis result of self assessment, the result of N-Gain, and media produced by the teachers, it can be known that the module being developed has been included into effective category. This is not apart from the role of instructor and training material arranged in details, systematic, and focus on the development of learning media and easy to understand (Sari et al., 2020).

If in the previous research most researchers did not develop the module, but giving the training directly, then in this research the module is developed which can ease the tutor in delivering the material of learning media development training. Even though there are some tutor using the module, but the material is not specific to make interactive learning 
media. For instance the material given just on the slide background, entering the figure, animation, and using the available template (Rusli et al., 2020; Santoso, 2019; Shedriko et al., 2018).

Different from the training module that has been developed in this research, the material developed is particular with deep discussion, and using Self Directed Learning (SDL) model until it enables the training participants to independently learn to produce interactive learning media.This is in line with the research results by (Silviana, 2014) who shows that the usage of valid and practical module can increase students' independence in learning. The module developed also has been in line with friendly standard module which enables the lears to study independently, systematically, and easy to be used and in accordance with the era development. This is supported by the research by (Sari et al., 2020) who shows that $45.8 \%$ of training success is affected by the material. Until the module being developed is also effective to be used and can increase the teachers' skill in making power point. This is also in line with the research result by (Dias $\mathrm{K}$ et al., 2019) who shows that the training of making power point by using the module can increase the training result in the amount of $78 \%$. Beside that this module can cover the weakness of the previous research which only used module in the form of Power Point Print Out which inhibits the teachers' participation, and the teachers' difficulty in understanding the material (Wulandari \& Iriani, 2018).

\section{Conclusion}

One competence indicator which must be owned by a teacher is using technology based learning media. One of the way to increase this competence is through the training of making learning media. So that the training can run effectively then needs a module which can ease the participants in mastering the material. In this research has been developed the module of power point optimization as the learning media. Based on the data of research result it can be concluded that the training module of power point optimization as the learning media is effective in increasing one of teachers' professional competence at SD IT in Kerinci Regency. This can be seen from the result of teachers' mastery evaluation on the stages of making the learning media which almost in each chapter the average gives score 3 and 4 . Beside that the existence of intact learning media produced by the teachers also indicate that the teachers have been capable of making technology based learning media. This research was limited on SD IT teachers in Kerinci Regency.

\section{Acknowledgement}

Thank you very much to Kemenristekdikti who has funded this research through Beginner Lecturer Research (PDP) grant until this research could be conducted well in accordance with the research contract of budget in 2019 Number 255/II.3AU/KEP/LPPMSTKIP.M/2019. Beside that the researcher also thank the validator who has contributed in perfecting the training module of power point optimization as the learning media.

\section{References}

Alimudin, E., Yuliati, T., \& Nugraha, N. B. (2019). Pelatihan Media Pembelajaran dengan Ms. Office Power Point bagi Guru SMA IT Plus BAZMA Brilliant Dumai. Madani: Indonesian Journal of Civil Society, 1(1), 11-16. https://doi.org/10.35970/madani.v1i1.28

Alwi, S. (2017). Problematika Guru Dalam Pengembangan. Itqan, 8(2), 145-167.

Ankad, R. B., Shashikala, G. V., Herur, A., Manjula, R., Chinagudi, S., \& Patil, S. (2015). PowerPoint presentation in learning physiology by undergraduates with different learning styles. Advances in Physiology Education, 39(1), 367-371. https://doi.org/10.1152/advan.00119.2015

Berk, R. A. (2011). Research on PowerPoint: From Basic Features to Multimedia. International Journal of Technology in Teaching and Learning, 7(1), 24-35. 
Cut Fitriani, Murniati AR, N. U. (2017). Kompetensi Profesional Guru Dalam Pengelolaan Pembelajaran Di Mts Muhammadiyah Banda Aceh. Jurnal Administrasi Pendidikan: Program Pascasarjana Unsyiah, 5(2), 88-95.

Dias K, S. P., Magdalena, R., Aditya, F., Setiawan, A., \& M, G. C. (2019). Pelatihan Pembuatan Presentasi Dengan Ms Office Power Point Bagi Masyarakat Desa Sampora. ABDAMAS, 375-378.

Diputra, K. S. (2016). Pengembangan Multimedia Pembelajaran Tematik Integratif Untuk Siswa Kelas Iv Sekolah Dasar. JPI (Jurnal Pendidikan Indonesia), 5(2), 125. https://doi.org/10.23887/jpi-undiksha.v5i2.8475

Dwyer, C. (1993). Multimedia in Education. In Educational Media International (Vol. 30, Issue 4). the UNESCO Institute for Information Technologies in Education. https://doi.org/10.1080/0952398930300402

Fahriannur, A., \& Siswanto, M. (2016). Pelatihan Ms . Excel , Ms . PowerPoint, dan Webblog Sebagai Inovasi Pembelajaran Menarik. Prosiding Seminar Hasil Penelitian Dan Pengabdian Masyarakat Dana BOPTN, 263-267.

Hadibin, M. M., Purnama, B. E., \& Kristianto, G. (2012). Pembangunan Media Pembelajaran Teknik Komputer Jaringan Kelas X Semster Ganjil Pada Sekolah Menengah. Indonesian Journal on Networking and Security (IJNS), 9330(1), 1-6. https://doi.org/http://dx.doi.org/10.1123/ijns.v4i3.295

Jones, A. M. (2003). The use and abuse of PowerPoint in Teaching and Learning in the Life Sciences: A Personal Overview. Bioscience Education, 2(1), 1-13. https://doi.org/10.3108/beej.2003.02000004

Kirova, A., Massing, C., Prochner, L., \& Cleghorn, A. (2016). Shaping the "Habits of mind" of diverse learners in early childhood teacher education programs through powerpoint: An illustrative case. Journal of Pedagogy, 7(1), 59-78. https://doi.org/10.1515/jped2016-0004

Nouri, H., \& Shahid, A. (2005). The Effect of PowerPoint Presentations on Student Learning and Attitudes. Perspectives on Accounting Education, 2(1), 53-73.

Pate, A., \& Posey, S. (2016). Effects of applying multimedia design principles in PowerPoint lecture redesign. Currents in Pharmacy Teaching and Learning, 8(2), 235-239. https://doi.org/10.1016/j.cptl.2015.12.014

Permadina Kanah Arieska, Zainatul Mufarrikoh, F. A. S. (2017). Pelatihan Pembuatan Media Pembelajaran Interaktif Dengan Microsoft Powerpoint Bagi Yayasan Ittaqu Surabaya. Community Development Journal, 1(1).

Pinahayu, E. A. R., \& Sriyono. (2019). Ms Word And Ms Power Point Training For Development Of. Journal of Community Service, 1(1), 195-199.

Rasmawan, R. (2018). Development of Chemistry Module for Junior High School Based on Inquiry Accompanied by Performance-Based Assessment. 7(2), 111-119. https://doi.org/10.23887/jpi-undiksha.v7i2.10617

Rozie, F. (2018). Persepsi Guru Sekolah Dasar Tentang Penggunaan Media Pembelajaran Sebagai Alat Bantu Pencapaian Tujuan Pembelajaran. Widyagogik, 5, 1-12. https://doi.org/10.21107/widyagogik.v5i2.3863

Rusby, Z. et al. (2017). Upaya Guru Mengembangkan Media Visual dalam Proses Pembelajaran Fiqih di MAN Kuok Bangkinang Kabupaten Kampar. Al-Hikmah, 14(1), 18-37.

Rusli, M., Winarso, E., \& Putri, D. (2020). Pelatihan Microsoft Powerpoint Dasar Bagi Guru Guru Paud Kabupaten Bekasi. Jurnal Pengabdian Kepada Masyarakat, 1(1), 12-15. 
Santoso, B. (2019). Peningkatan Keterampilan Media Pembelajaran Interaktif Menggunakan Microsoft Office Powerpoint, Photoshop Dan Corel Draw Untuk Guru Tk (lgtki) Ngemplak Sleman. PROSIDING SEMINAR HASIL PENGABDIAN MASYARAKAT, November, 91-96.

Sari, I. P., Novitasari, A. T., \& Miftah, Z. (2020). Efektivitas Pelatihan Membuat Media Pembelajaran Interaktif Dengan Macro Powerpoint Bagi Guru. Research and Development Journal of Education, 6(2), 31. https://doi.org/10.30998/rdje.v6i2.6107

Shah, I., \& Khan, M. (2015). Impact of Multimedia-aided Teaching on Students' Academic Achievement and Attitude at Elementary Level. US-China Education Review A, 5(5), 349-360. https://doi.org/10.17265/2161-623X/2015.05.006

Shanmugam, K., \& Balakrishnan, B. (2017). Kerangka Panduan Efektif Pengajaran Dan Pemudahcaraan (PdPc) Sains Menggunakan Information Communication Technology (ICT) di Sekolah Jenis Kebangsaan Tamil (SJK) (TAML). Sains Humanika, 10(1), 25-35. https://doi.org/10.11113/sh.v10n1.1322

Shedriko, S., Setiawan, H. S., \& Kusmayadi, K. (2018). Pelatihan Perangkat Lunak Powerpoint untuk Meningkatkan Kinerja Guru di SD dan SMP 19 Muhammadiyah Sawangan Depok. Jurnal PkM Pengabdian Kepada Masyarakat, 1(02), 151. https://doi.org/10.30998/jurnalpkm.v1i02.2552

Silviana, W. (2014). Modul Powerpoint Pada Program Pendidikan D1 (Prodistik) Untuk Semester li Di Man Mojosari. Jurnal Pendidikan, 1(1), 1-6.

Sulfemi, W. B. (2019). Kompetensi Profesionalisme Guru Indonesia dalam Menghadapi MEA. Prosiding Seminar Nasional STKIP Muhammadiyah Bogor., 106, 62-77.

Suprapti, E. (2016). Pengembangan Perangkat Pembelajaran Matematika Model Kooperatif Tipe STAD dengan Media Powerpoint Ispring pada Materi Jajargenjang, LayangLayang dan Trapesium di Kelas VII SMP. MUST: Journal of Mathematics Education, Science and Technology, 1(1), 57. https://doi.org/10.30651/must.v1i1.98

Supriyono, A. (2017). Pengaruh Kompetensi Pedagogik, Profesional, Dan Motivasi Kerja Terhadap Kinerja Guru Sekolah Dasar. Jurnal Pendidikan, 18(2), 1-12. https://doi.org/10.33830/jp.v18i2.269.2017

Thiagarajan. (1974). Instructional Development for Training Teachers of Exceptional Children: A Sourcebook. (Issue Mc). Indiana Univ., Bloomington.

Wulandari, M., \& Iriani, A. (2018). Pengembangan Modul Pelatihan Pedagogical Content Knowledge ( PCK ) Dalam Meningkatkan Kompetensi Profesional dan Kompetensi Pedagogik Guru Matematika SMP. Kelola: Jurnal Manajemen Pendidikan, 5(2), 177189.

Yunus, M. (2016). Profesionalisme Guru Dalam Peningkatan Mutu Pendidikan. Lentera Pendidikan: Jurnal IImu Tarbiyah Dan Keguruan, 19(1), 112-128. https://doi.org/10.24252/lp.2016v19n1a10 